\title{
Case Study: Geochemistry and Mineralogy of Copper Mine Tailings in Northern Central-Chile
}

\author{
K. Berkh ${ }^{(\bowtie)}$, D. Rammlmair, M. Drobe, and J. Meima \\ Federal Institute for Geosciences and Natural Resources, Hanover, Germany \\ Khulan. berkh@bgr.de
}

\begin{abstract}
Selected mine tailings in northern-central Chile were geochemically and mineralogically studied for their economic potential and environmental impact. High bulk Co content up to $1500 \mathrm{ppm}$ and $\mathrm{Cu}$ content up to $9100 \mathrm{ppm}$ are caused by Co-bearing pyrite, chalcopyrite, and their secondary products such as malachite and $\mathrm{Co}-\mathrm{Cu}$-carrying Fe-hydroxides. Due to high amount of sulfide minerals acid mine drainage (AMD) is forming in the oxidized upper part of the tailing, which makes a retreatment in dispensable to reduce the environmental impact.
\end{abstract}

Keywords: Mine tailings - Geochemistry $\cdot$ Mineralogy $\cdot$ Cobalt $\cdot$ Copper Reprocessing

\section{Introduction}

Since Chile is the largest $\mathrm{Cu}$ producing country with the biggest reserves, Chilean mining industry generates huge quantities of mining residues, amongst others in the form of tailings dumps. The fact that some of them were generated many decades ago, where process technology was inadequate in comparison to today, makes some of them economically interesting. Due to advanced weathering, the tailings, which are potentially acid producing, bear an environmental hazard. Therefore, our aim is to investigate the geochemistry and mineralogy of the tailings in order to determine their economic potential and environmental impact.

The studied mine tailings dump is located in the region of Coquimbo, where an arid Mediterranean climate with mean annual temperature of $14.6^{\circ} \mathrm{C}$, precipitation of $132 \mathrm{~mm}$, and evaporation of about $1702 \mathrm{~mm}$ prevails (Mora et al. 2007). Geologically, the region is characterized by Early Cretaceous Chilean Manto-type (volcanic-hosted stratiform) $\mathrm{Cu}$ deposits (Kojima et al. 2003) that are the most probable source of the studied tailings.

\section{Methods and Approaches}

Eight drill cores with lengths of seven meters were taken from the tailings dump (Fig. 1). Bulk geochemistry of homogenized material for each meter was investigated using a standard WDXRF. Mineralogy was studied on representative grain 
concentrates obtained by gravity separation. Abundance of the minerals was analyzed by MLA and composition of the minerals was examined by EPMA.

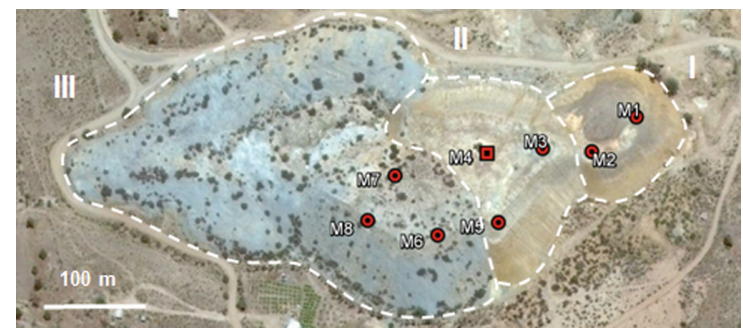

Fig. 1. Drill cores positions (M1-M8) in three heaps (I-III)

\section{Results and Discussion}

The tailings material consists of alternating layers of sand, silt and clay. According to geochemical pattern, the tailings dump can be subdivided into three groups, as shown in Fig. 1. Heap I and II are enriched in Fe and Co (Fig. 2). Special feature of heap I is a depletion in $\mathrm{S}$ and $\mathrm{Ca}$ but a high percentage of loss on ignition (LOI). It may point to a weathered part of the tailings dump, where oxidation of pyrite results in dissolution of calcite and accumulation of water bearing secondary clay minerals. Heap III contains high amounts of host rock and therefore elevated contents of $\mathrm{Si}, \mathrm{Al}, \mathrm{Mg}, \mathrm{Na}, \mathrm{K}$ and $\mathrm{P}$ can be seen. It is strongly enriched in $\mathrm{Cu}$ but only at the near surface level (Fig. 2).
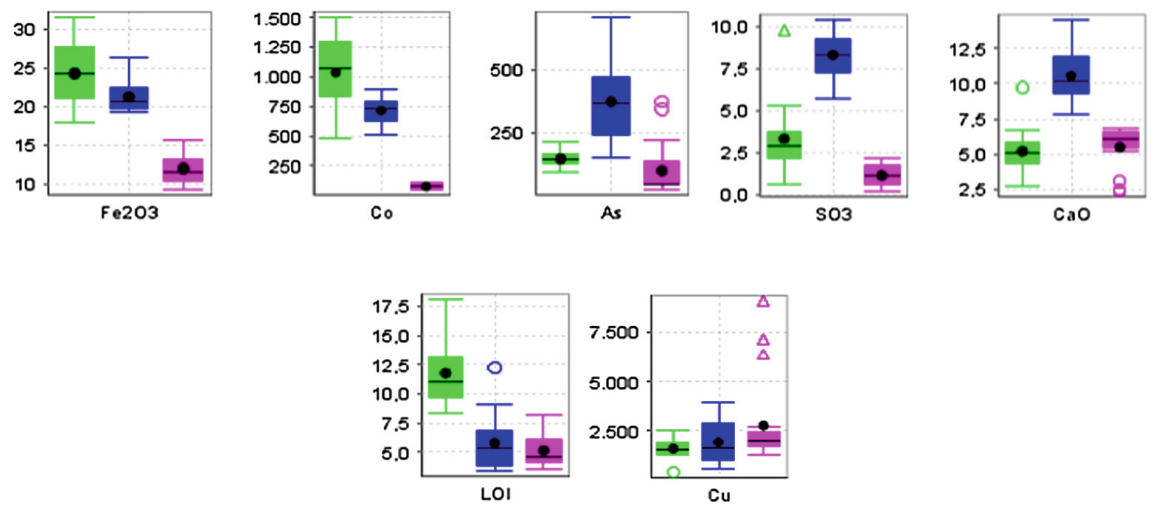

Fig. 2. Bulk content of relevant elements in three heaps ( $\square-$ heap I, $\square-$ heap II, $\square-$ heap III)

Primary gangue minerals in heap I and II are epidote, quartz, andradite, and albite pointing towards skarn mineralization. The only difference between the two heaps is the absence of calcite in the heap I confirming the bulk geochemistry. The most common primary ore mineral in both heaps is pyrite, which occurs as liberated grains. Three types of pyrite were identified. The first type is pure pyrite. The second type has an As-rich rim with up to $8.7 \mathrm{wt} \%$ As (Fig. 3a) and is predominantly present in the heap II resulting in 
an elevated bulk content of As (Fig. 1). The third type contains a significant amount of Co. Hereby, the Co concentration increases from rim to core and can reach up to $3.8 \mathrm{wt}$ $\%$. Additional trace elements are e.g. up to $0.5 \mathrm{wt} \% \mathrm{Ni}, 0.1 \mathrm{wt} \% \mathrm{Cu}$, and $0.2 \mathrm{wt} \% \mathrm{Cd}$. Remaining primary ore minerals are magnetite, hematite and trace amounts of chalcopyrite. They also occur as well liberated grains and are occasionally inter grown with each other. These minerals do not contain significant amounts of trace elements.
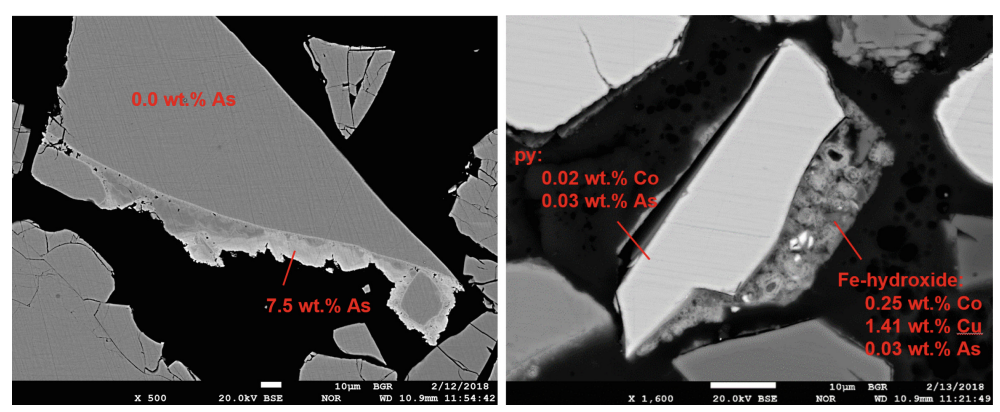

Fig. 3. BSE images of the pyrite grains: a As-rich rim on pyrite and b pyrite rimmed by Fehydroxide with significant amounts of $\mathrm{Co}$ and $\mathrm{Cu}$

Secondary phases are gypsum and Fe-hydroxides as weathering products of calcite and pyrite (Fig. 3b) and preferentially occur in heap I. Such in-situ precipitation of Fehydroxides can only take place at near neutral $\mathrm{pH}$ proving an initial occurrence of calcite as a buffering agent in the strongly weathered heap I. The Fe-hydroxides contain high concentrations of $\mathrm{Co}$ (up to $0.9 \mathrm{wt} \%$ ), $\mathrm{Cu}$ (up to $2.5 \mathrm{wt} \%$ ) and $\mathrm{Ca}$ (up to $4.3 \mathrm{wt} \%$ ), pointing to a dissolution of pyrite, chalcopyrite and calcite and fixation of released metals in Fe-hydroxides. The analyzed saturated soil extraction had a $\mathrm{pH}$ of 2 . Its $\mathrm{Co}$ and $\mathrm{Cu}$ contents were 103 and $136 \mathrm{mg} / \mathrm{l}$ respectively, whereas $\mathrm{Hg}, \mathrm{Cd}, \mathrm{As}, \mathrm{Zn}$ and $\mathrm{Pb}$ contents remained under $2.4 \mathrm{mg} / \mathrm{l}$. Especially, the $\mathrm{Co}$ and $\mathrm{Cu}$ values exceed the international guidelines (IFC 2007 and Gusek and Figueroa 2009) by more than a factor of 100.In fact, the potential for AMD is high in the oxidized parts of the heaps.

The heap III predominantly consists of gangue minerals. The most common mineral is quartz followed by albite, anorthite, micas, K-feldspar, amphibole, epidote, pyroxene, chloride, and calcite. A Minor amount of Fe-oxides and chalcopyrite exists, either as liberated grains or finely intergrown with gangue minerals. Chalcopyrite is strongly replaced by $\mathrm{Fe}$-hydroxides and $\mathrm{Cu}$-carbonates along grain boundaries and micro fractures.

\section{Conclusion}

Bulk geochemistry provides a good prediction of the mineralogy. Elevated amounts of $\mathrm{Fe}, \mathrm{Co}$, and $\mathrm{S}$ in the heaps I and II correspond to Co-bearing pyrite-rich waste material. In contrast, heap III consists of host rock forming elements resulted by non-sulfidic gangue mineral waste. From an economic point of view, Co is the only valuable metal 
in the heap I and II. For the extraction magnetic separation should be performed to eliminate high amounts of magnetite. Heap I contains extensive amounts of Co- and $\mathrm{Cu}$-rich Fe-hydroxides that usually coat pyrite grains. Therefore, leaching can be directly applied to extract acid soluble $\mathrm{Co}$ and $\mathrm{Cu}$ and also to liberate pyrite grains. Otherwise, pyrite cannot be floated. Afterwards, pyrite from both sulfidic heaps can be floated and Co can be extracted by bioleaching. In case of heap III, only the uppermost first meter, which is $\mathrm{Cu}$-rich, should be treated. $\mathrm{Cu}$ occurs preferentially as acid soluble mineral such as malachite and $\mathrm{Cu}$-rich Fe-hydroxides. However, calcite would have to be removed by gravity separation to reduce the consumption of sulfuric acid. Otherwise, itis economically not feasible. From an environmental point of view, heap III poses no environmental risk because it does not host AMD potential. Oxidation of minor chalcopyrite will be buffered by the carbonate content. In turn, the sulfidic tailings should be immediately treated, because the potential of AMD generation due to heavy rains is high. The hazardous potential of the impoundment should not be underestimated because of agricultural activities in the vicinity.

Acknowledgements. This investigation is supported by DERA the German Mineral Resources Agency of BGR.

\section{References}

Gusek JJ, Figueroa LA (2009) Mitigation of metal mining influenced water (Management Technologies for Metal Mining Influenced Water, vol 2), Soc Min Metall Explor. Littleton, Colorado

IFC (2007) Environmental, health and safety guidelines for mining. International Finance Corporation, World Bank Group, DC, $33 \mathrm{p}$

Kojima S, Astudillo J, Rojo J, Tristá D, Hayashi K (2003) Ore mineralogy, fluid inclusion, and stable isotopic characteristics of stratiform copper deposits in the coastal Cordillera of Northern Chile. Miner Deposita 38:208-216

Mora F, Tapia F, Scapim SA, Martins EN (2007) Vegetative growth and early production of six olive cultivars, in Southern Atacama Desert, Chile. J Cent Eur Agric 8(3):269-276

Open Access This chapter is licensed under the terms of the Creative Commons Attribution 4.0 International License (http://creativecommons.org/licenses/by/4.0/), which permits use, sharing, adaptation, distribution and reproduction in any medium or format, as long as you give appropriate credit to the original author(s) and the source, provide a link to the Creative Commons license and indicate if changes were made.

The images or other third party material in this chapter are included in the chapter's Creative Commons license, unless indicated otherwise in a credit line to the material. If material is not included in the chapter's Creative Commons license and your intended use is not permitted by statutory regulation or exceeds the permitted use, you will need to obtain permission directly from the copyright holder.

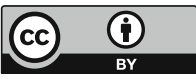

